\title{
悪性眼球突出症の経副鼻腔的眼窩減圧術
}

\author{
柿木 章伸 ${ }^{12}$. 竹内 俊二11 ・ 岸本 誠司 ${ }^{11}$ \\ 安岡 一夫 ${ }^{2)}$ ・細木 敬三 ${ }^{2)}$ ・玉并 嗣彦3
}

\section{Transantral Orbital Decompression for Malignant Exophthalmos; A Case Report}

\author{
Akinobu Kakigi, Shunji Takeuchi, Seiji Kishimoto, \\ Kazuo Yasuoka, Keizou Hosogi and Akihiko Tamai \\ (Kochi Medical School)
}

\begin{abstract}
A 55-year-old female with severe exophthalmos of $27 \mathrm{~mm}$ was treated with the WalshOgura method.

CT scan and MRI showed that the severe exophthalmos was caused by enlargement of the extraocular muscles. The patient's left eye was treated with transantral orbital decompression.

In addition, the infraorbital nerve and part of the inferior orbital rim were removed. Four months after surgery, the reduction in proptosis was $7 \mathrm{~mm}$. The patient's visual acuity was improved and she attained a satisfactory cosmetic result.

After the operation, hypesthesia of the cheek was transient, but there were no other complications.
\end{abstract}

Key words: malignant exophthalmos, transantral approach, orbital decompression

はじめに

悪性眼球突出症は，バセドウ病を中心とする 内分泌性眼球突出のうち，特に進行性で重篤な あのをいう。

本症の治療方法として, ステロイド療法, 放 射線療法などの保存的治療が第一選択となるが, 他に手術療法が行われることあある。との手術
療法の適応としては，保存的治療に抵抗性のも の, 眼球突出度が特に高度で失明の危険がある 場合などである。

今回，我々は失明寸前の悪性眼球突出症に対 し, Walsh-Ogura の術式”の変法による眼窩減 圧術を行い，視力の回復と形態上の改善が得ら れたのでこれを報告する.

1) 高知医科大学耳鼻咽喉科学教室

2) 高知医科大学眼科学教室

3 ) 高知医科大学眼科学教室（現：鳥取大学医学部眼科学教室） 


\section{症 例}

患者 : 55歳, 女性.

主訴：両側眼球突出, 視力障害.

家族歴：娘；バセドウ病.

現病歴：昭和62年 4 月頃より全身倦㤐感, 手 指振戦，軽度眼球突出が出現し，同 6 月近医を 受診、バセドゥ病の診断にて治療を受けたが, 7 月頃より結膜充血, 複視, 眼球突出の増悪, 11月には両側の視力低下もきたしたため同 12 月 当院眼科に入院した.

入院時所見 : 両側の眼瞼浮腫, 結膜充血, 角 膜にびらんを認め，眼球突出は Hertel 眼球突 出計にて右眼 $22 \mathrm{~mm}$, 左眼 $20 \mathrm{~mm}$, 視力は右眼 50 $\mathrm{cm}$ 手動弁, 左眼 0.05 (矯正視力), 兔眼と眼球 運動障害が右眼に存在した。甲状腺機能は, 前 医による治療により正常化していた。

CT, MRI では, 全ての外眼笳に高度の肥厚 がみられ，視神経は眼简内容の増加のため長軸

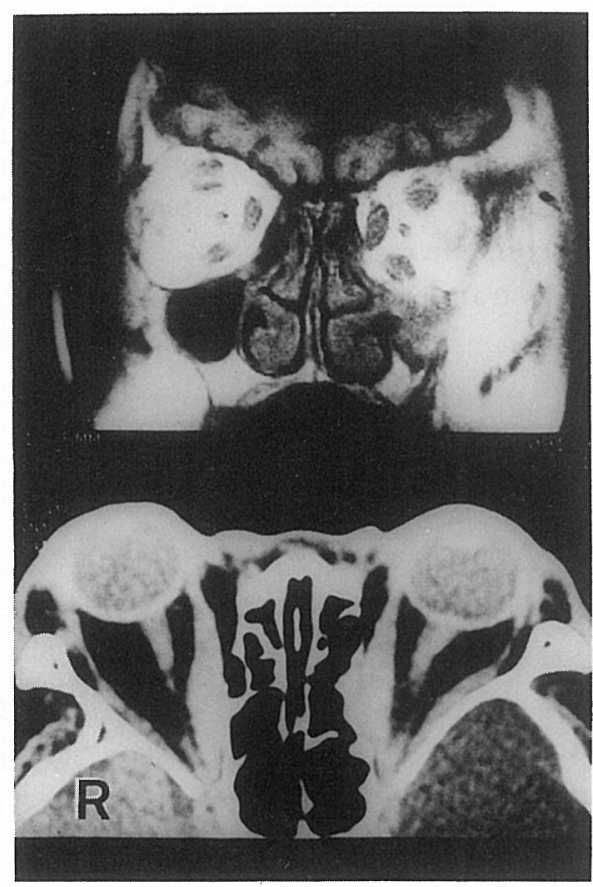

図 1

上 : MRI にて全ての外眼筋の腫大が認められる.

下：CT にて眼球实出，外眼筋腫大，視神経の圧 迫と延長汃認められる。

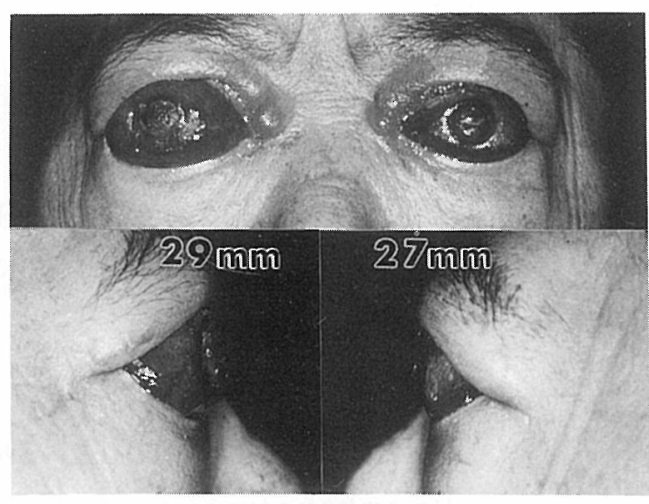

図 2 眼球突出度

右眼 : $29 \mathrm{~mm}$ 左眼 : $27 \mathrm{~mm}$

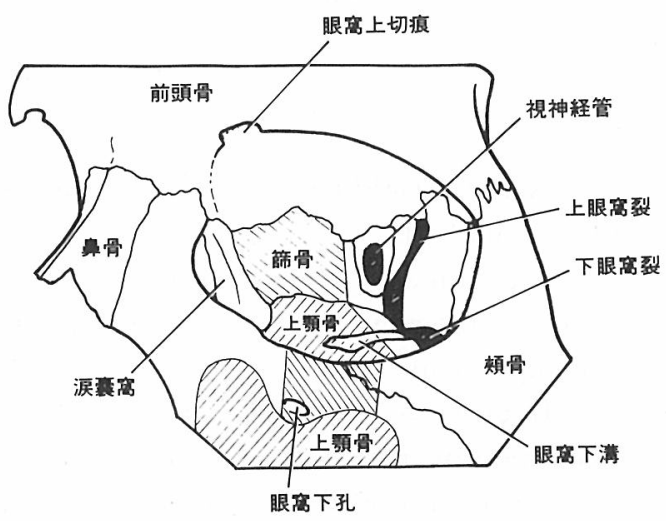

図3a

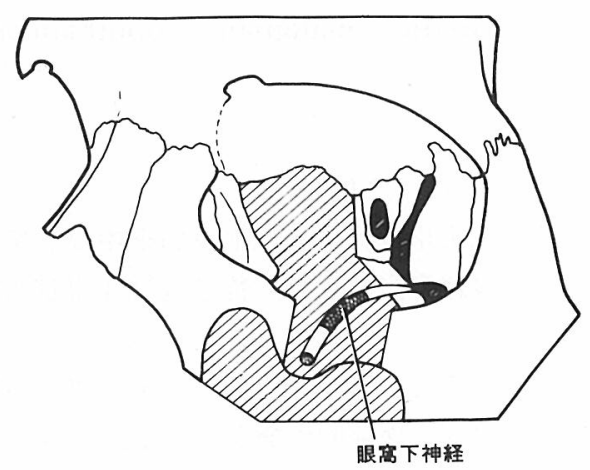

図 $3 \mathrm{~b}$

図 3 Walsh-Ogura の変法

a : 経上䫟洞的に眼窩下壁, 内側壁, 眼窩下壁の 除去範囲を示す (斜線部)。

b ：眼窩下神経の切断部位を示す. 
方向に引き延ばされ眼窩先端付近で外眼筋によ り圧迫を受けていた（図1）.

入院後経過：眼症状は次第に悪化し，視力は， 右眼が光覚消失，左眼 $10 \mathrm{~cm}$ 手動弁，両眼と屯 閉瞼不能であり，角膜混濁，結膜充血，眼球運 動む高度に制限されてきた。 以上の経過より悪 性眼球突出症之䛦断された。

症状は進行性であり，高度なため手術的治療 の適応と判断され，当科紹介となり，昭和63年 7 月眼窩減圧術を施行した。術前眼球突出度は, 右眼 $29 \mathrm{~mm}$, 左眼 $27 \mathrm{~mm}$ であった（図 2 ）.

手術方法 : 手術は，視機能の残存している左 眼にのみ施行した。術式は, Walsh-Ogura の術 式の变法を用い，経上顎洞的に眼窩下壁，内側 壁，眼窩下縁の一部，眼窩下神経を除去した (図 $3 a, b$ ).

手術所見：全身麻酔下に犬歯窩切開に上り上 顎洞を開放し，洞内の粘膜を除去後，顕微鏡下 に眼窩下神経を保存しながら眼窩下壁，内側壁 を除去し，洞内に膨隆してきた眼窩骨膜に切開 を加えたととろ，眼窩内の脂肪織が篩骨洞及び 上顎洞へ脱出した(図 4). この時点で眼球突出 度は $24 \mathrm{~mm}$ となった。更に，眼球突出の減少 を図るために眼窩下神経を切断し，橋状に残し ていた眼窩下縁の一部屯追加切除した．乙の時 点で眼球突出度は $23 \mathrm{~mm}$ と $4 \mathrm{~mm}$ 減少した。 続いて，眼科的に球結膜下の増生した肉芽組織 を除去した。

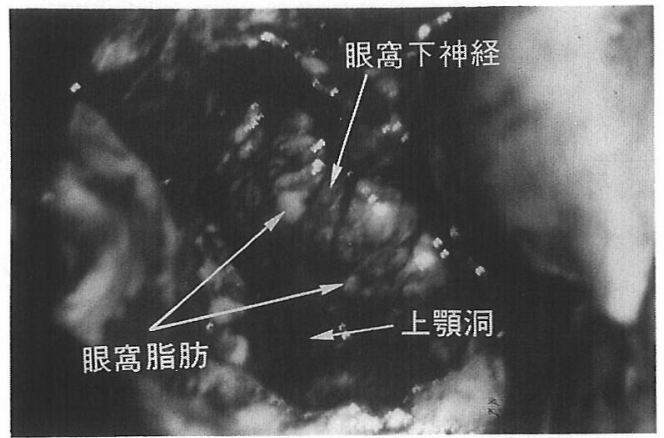

図 4 眼窩下壁を除去し，眼窩脂肪が上顎洞内に脱出 している.
術後経過: 術後 4 力月目の眼球突出度は 20 $\mathrm{mm}$ と $7 \mathrm{~mm}$ の減少を認め，軽く閉瞼させると $2 \mathrm{~mm}$ 位開瞼しているが強く閉瞼させると完全 に閉瞼可能となった(図 5 )。眼球運動は改善さ れ，視力あ0.01と改善した。

術後の MRI では，眼窩内容物が上顎洞内に 脱出し眼窩減圧が行われている状態がよく分か る(図 6 ).

尚，既に視機能の失われていた右眼について は昭和63年 9 月眼科にて眼球摘出術が施行され， 義眼を插入した。

\section{考察}

悪性眼球突出症の治療法には，ステロイド， 放射線，手術療法がある。ステロイド，放射線 療法は，急性期で眼症状が軽度の症例に行われ る.手術療法の適応として最も重要な症状に視 力・視野障害があげられる，そのほかの適応之 しては，ステロイド療法抵抗例，放射線療法抵 抗例, 進行性眼球突出, 眼球運動障害, 閉瞼障

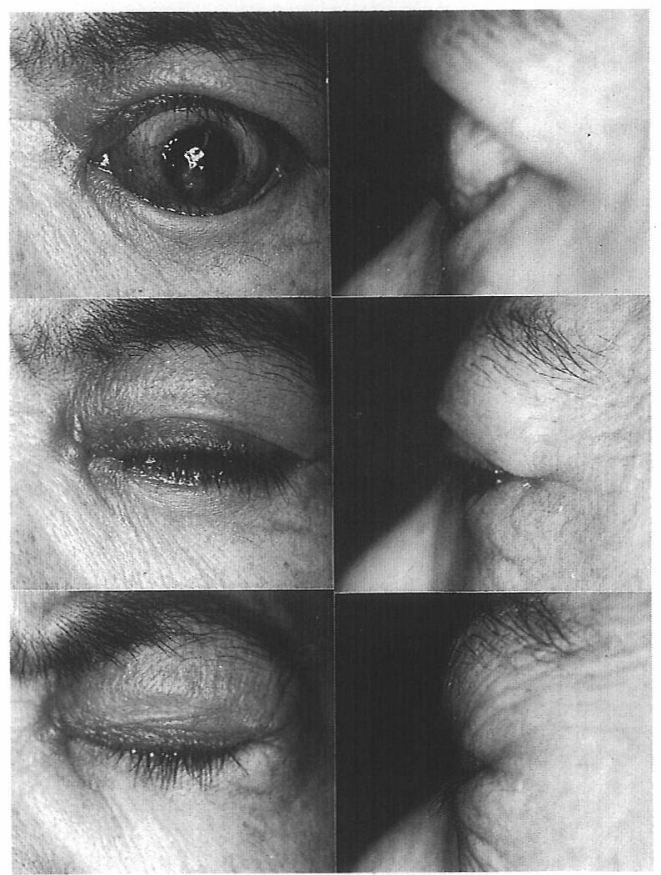

図 5 術後眼球突出は改善し，軽く閉瞼させると 約 $2 \mathrm{~mm}$ 開瞼しているが，強く閉瞼させる と閉瞼可能となった。 
害，角膜潰瘍，結膜充血，涙液分泌増加， CT 像にて外眼筋の眼窩尖端部での肥厚，形態上問 題がある場合などがあげられているい 5 .

今回我々の経験した症例では，右眼はすでに 視機能が消失して拉り, CT, MRI で両視神経が, 増生した眼窩内容により高度に圧迫を受けてお り，左眼についても早晚視機能の消失が予想さ れたとと，外見的にも問題があったととより， 眼窩減圧術の適応と判断された。

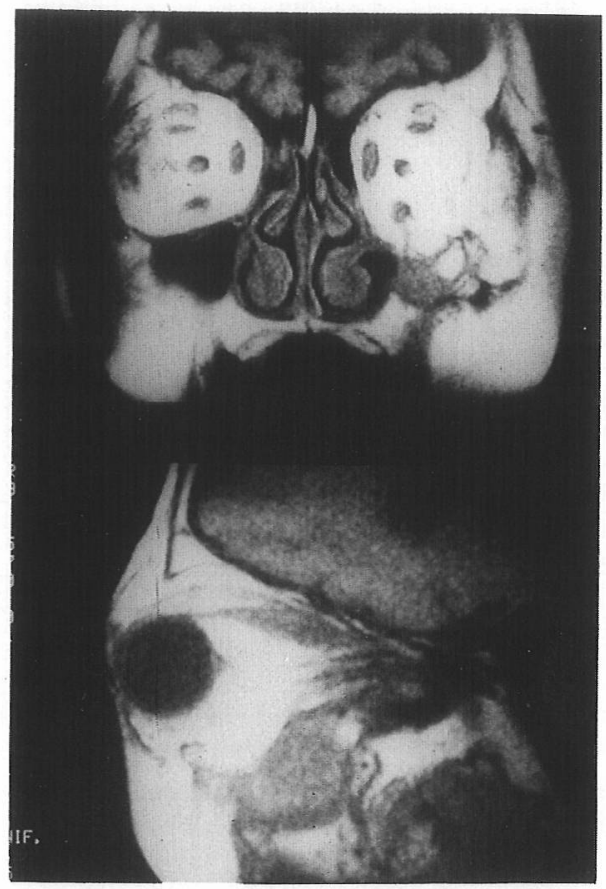

図 6 術後の MRI 所見

左上顎洞内に眼窩内容が脱出し, 眼球突出の改善 が認められる。

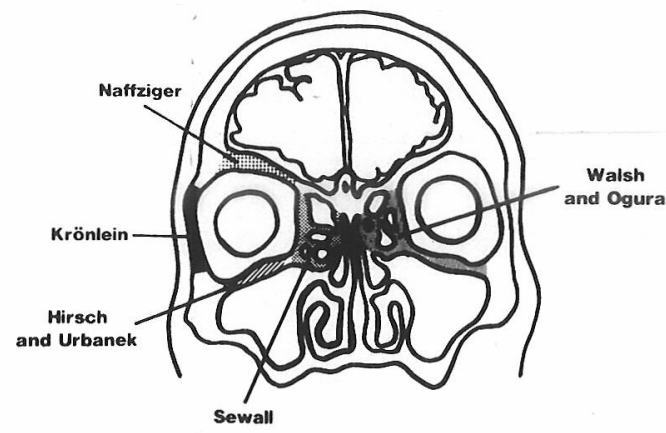

図 7 種々の眼窩減圧術を示す。
手術方法は図 7 に示したようにいくつかある が，Walsh-Ogura の術式が最も減圧量が大き いとと，顔面の皮切が不要なとと，開頭術を要 しないなよ゙の利点があり本症例に対してはこの 術式を用いた1)6)7.

Walsh-Ogura の術式による眼球突出度の改 善は表 1 に示すように $1 \sim 12 \mathrm{~mm}$, 平均約 4〜7

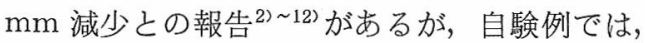
眼球突出度がより高度であったので原法に加え 眼窝下神経切断と眼窩下縁部分切除を施行した。

その結果, 眼球突出度は $7 \mathrm{~mm}$ 減少して扔り 良好な結果が得られた。 また視力, 眼球運動, 閉臉障害, 角膜潰瘍, 球結膜充血の改善力゙認め られた。合併症として，副鼻腔炎，䯣液鼻漏， 口腔上顎洞瘻, 複視の増悪, 流涙障害などの報

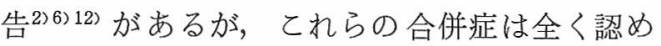
られなかった，更に，眼窩下神経切断による術 後一過性に頓部のしびれ感が出現したが $2 \sim 3$ 力月後に徐々に消失，乙のこ上は，切断した神 経が組織上を伝って再生したととも考えられ る. 眼窩下縁除去による顔面の変形屯きたして いない。

\section{結語}

悪性眼球突出症の 1 例に眼窩減圧術を施行し 著効を得た。本症例では，高度の眼球突出に対 L, Walsh-Ogura の術式に加え眼窩下神経切断 之眼窩下縁部分切除を行い，眼䆚减圧量を多く するととができた。

表 1 諸家の経上顎洞的眼窩減圧術による眼球突 出度の改善度を示す.

\begin{tabular}{|c|c|c|}
\hline 報告者 & 範囲 $(\mathrm{mm})$ & 平均 $(\mathrm{mm})$ \\
\hline Ogura ${ }^{2)}$ & $2-12$ & \\
\hline Hanabury $5^{3)}$ & $1-9$ & 4.3 \\
\hline Morax and Hurbli ${ }^{5)}$ & $4-7$ & \\
\hline Weisman and Savino ${ }^{6)}$ & $\begin{array}{l}\text { 術直後: 4-7 } \\
\text { 術後2力 月 : 5-9 }\end{array}$ & \\
\hline Gorman $ら^{7)}$ & $1.5-10$ & 4.0 \\
\hline DeSanto and Gorman ${ }^{8)}$ & $1-10$ & 4.5 \\
\hline MaCord ${ }^{9)}$ & $4-7$ & 6 \\
\hline Stuart and Shorr ${ }^{12)}$ & $5-10.5$ & 7.75 \\
\hline
\end{tabular}


稿を終えるに臨み，御校閲を頂いた齋藤春雄教授に 深謝いたします。

\section{参考文献}

1) Walsh TE and Ogura JH : Transantral orbital decompression for malignant exopthalmos. Laryngoscope $65: 544 \sim 568,1957$.

2 ) Ogura JH : Surgical result of orbital decompression for malingnant exophthalmos. J Laryngol Otol $92: 181 \sim 195,1978$.

3) Hanarury MR, Cole TB, Clark CE, et al : Surgical treatment for malignant exophthalmos of endocrine origin. Laryngoscope $94: 1193 \sim 1197$, 1984.

4) Schaefer SD, Merritt JH and Close LG : Orbital decompression for optic neuropathy secondary to thyroid eye disease. Laryngoscope $98: 712 \sim 716$, 1988.

5 ) Morax S and Hubli $\mathrm{T}:$ Choice of surgical treatment for Graves' disease. J Craniomaxillofac Surg $15:$ 174 181, 1978.

6) Weisman RA and Savino PJ : Management of endocrine orbitopathy. Otolaryngol Clin North Am 21 : 93 102, 1988.
7) Gorman CA, DeSanto LW, MacCarty CS, et al : Optic neuropathy of Graves' disease. N Engl J Med $290: 70 \sim 75,1974$.

8) DeSanto LW and Gorman CA : Selection of patients and choice of operation for orbital decompression in Graves' ophthalmopathy. Laryngoscope $83:$ 945 959, 1973.

9) Clinton D and McCord JR : Orbital decomperssion for Graves' disease. Ophthalmology $88: 533$ $\sim 541,1981$.

10) Lamberg BA, Grahne B, Tommila V, et al : Orbital decompression in endocrine exophthalmos of Graves' disease. Acta Endocrinol 109 : 335 340, 1985.

11) Hecht SD, Guibor P, Wolfley D, et al : Orbital dissection defatting technique for Graves' disease. Ann Ophthalmol $16: 314 \sim 318,1984$.

12) Seiff SR and Shorr $N$ : Nasolacrimal drainage system obstruction after orbital decompression. Am J Ophthalmol $106: 204 \sim 209,1988$.

$\left(\begin{array}{l}\text { 原稿受付 : 平成元年10月 } 23 \text { 日 } \\ \text { 原稿採択 : 平成元年11月 } 7 \text { 日 } \\ \text { 別刷請求先 : 柿木章伸 } \\ \text { 干783 高知県南国市岡豊町小蓮 } \\ \text { 高知医科大学耳鼻咽喉科学教室 }\end{array}\right)$

